\title{
Effect of Arginine on Growth Characters of Two Maize Hybrids under Water Deficit conditions
}

\author{
Amal G. Ahmed, Nabila M. Zaki and Hassanein M.S.
}

Field Crops Research Department, Agricultural and Biological Research Division, National Research Centre, 33 El Buhouth St., 12622 Dokki, Giza, Egypt

\author{
Received: 15 Jan. 2020 / Accepted 30 Mar. 2020 / Publication date: 15 April 2020
}

\begin{abstract}
Two field experiments were carried out at private farm Wadi El-Rayyan, El-Fayoum governorate, Egypt, during the two successive summer seasons of 2017 and 2018 to study the effect of skipping one irrigation with or without arginine on growth characters of two maize hybrids (Fine Seeds- 101 and T.W. 329). Normal irrigation gave the highest value in all growth characters under study followed by omitting the $5^{\text {th }}$ irrigation $+200 \mathrm{~cm}^{3} /$ fed., arginine. Fine Seeds- 101 cultivar significantly surpassed T.W. 329 cultivar in plant height $(\mathrm{cm})$, total dry weight / plant $(\mathrm{g})$, number of ear /plant, leaf area $\left(\mathrm{dm}^{2}\right)$, leaf area index, leaf area ratio, specific leaf area and specific leaf weight in both seasons. The interaction between maize cultivars and water shortage with or without arginine were significant in all growth characters in both seasons except leaf area $\left(\mathrm{dm}^{2}\right)$ and leaf area index. The best treatment for plant height $(\mathrm{cm})$, total dry weight / plant $(\mathrm{g})$, number of ear /plant, leaf area ratio, specific leaf area and specific leaf weight was normal irrigation + Fine seeds- 101. Also, the best treatment was omitting $5^{\text {th }}$ irrigation $+200 \mathrm{~cm}^{3} /$ fed., arginine with Fine Seeds- 101 cultivar for plant height $(\mathrm{cm})$, total dry weight / plant $(\mathrm{g})$ and leaf area ratio.
\end{abstract}

Keywords: Maize, cultivars, arginine, skipping, irrigation, growth characters

\section{Introduction}

Maize (Zea mays L.) is one major crop in summer season in Egypt. The actual water use by crop varies greatly due to the variation of seasons and locations, depending on the evaporative conditions of the atmosphere and the crop characteristics. Therefore the knowledge of the optimum amounts of water required for obtaining maximum yield and high quality is essential. It has been reported that soil moisture limits the growth of the plants before it reaches the permanent wilting point. Water stress affects every process in the plant, where it reduces cell turgor, the size of assimilation leaf area and number of potential sites for produced dry matter (Simpson, 1981). It is well established that water supply affects the growth and production of grown crop, limited soil moisture critically influenced the performance of maize plants by reducing plant height, weight and size of assimilating leaf area and dry matter accumulation (Hefni et al, 1993). Growth characters of maize were also affected by limited water supply, Ibrahim et al (1992). El-Sheikh (1994) and Zaki et al (2014) reported that the plant exposed to skipping one irrigation reduced growth characters. However, Egyptian maize cultivars may differ in their assimilation capacity and distribution of photosynthates between the various plant organs which could be referred to as "source and sink relation".

Water is generally considered the most limiting factor in higher plants. Exposing higher plants to water stress adversely affected plant growth and productivity (Ahmed et al, 2010).Therefore, it seems imperative to work for improving water use efficiency for major through increase inorganic ions or organic solutes (Simpson, 1981). The productivity of maize plants depends on the available amount of water, to evaluate the yield of maize cultivars it is useful to estimate the ability of maize plants to accumulate dry matter. Arginine is considered, as essential amino acids that founds is the structural protein, but in small quantities do not meet the needs of plant (Yang and Gao, 2007). It is one of the most common amino acids in natural proteins in plants. It is uses a source of nitrogen and transporter for it, so arginine represents $50 \%$ to $90 \%$ of the nitrogen in the seeds and vegetative tissue, respectively. In addition, it considered precursor for amines that have a role in many physiological processes as growth, cell division and plant protection from aging. Arginine constructed in green plastids with the contribution of some plant enzymes. Arginine, has a role in many processes,

Corresponding Author: Amal G. Ahmed, Field Crops Research Department, National Research Centre, 33 El Buhouth St., 12622 Dokki, Giza, Egypt. 
therefore, its importance lies in its effectiveness at all stage of plant growth as well as being an essential component of protein as constructing material for important componets such as nucleotide, porphyries and many co-enzymes (Tarraf and Zaki, 1999, El-Bassiouny et al, 2008, Winter et al, 2015 and Al- Hayani, 2018).

The aim of this investigation is to study the effect of water regime and arginine on growth characters of two maize hybrids.

\section{Materials and Methods}

Two field experiments were carried out at private farm Wadi El-Rayyan, El-Fayoum governorate, Egypt, during the two successive summer seasons of 2017 and 2018 to study the response of two maize hybrids to arginine grown under water shortage. Soil samples was taken at depth of $30 \mathrm{~cm}$ for mechanical and chemical analysis as described by Chapman and Pratt (1961). The mechanical and chemical analysis of the soil of the experimental site were illustrated in Table (1).

Table 1: Mechanical and chemical analysis of soil at experimental sites.

\begin{tabular}{ccccccccc}
\hline Sand\% & Silt\% & Clay\% & Texture & pH & $\begin{array}{c}\text { Organic } \\
\text { matter } \\
\mathbf{O . M . \%}\end{array}$ & $\begin{array}{c}\text { Available N } \\
\text { ppm }\end{array}$ & $\begin{array}{c}\text { Available K } \\
\text { ppm }\end{array}$ & $\begin{array}{c}\text { Available P } \\
\text { ppm }\end{array}$ \\
\hline 73.59 & 22.47 & 3.45 & Sandy & 8.00 & 0.49 & 84.00 & 134.00 & 12.5 \\
\hline
\end{tabular}

The experimental design was split plot design with six replications, where, the skipping irrigation and arginine [i.e. skipping the third irrigation with or without arginine $\left(200 \mathrm{~cm}^{3} / \mathrm{fed}\right.$.), skipping the fourth irrigation with or without arginine and skipping the fifth irrigation with or without arginine beside the control (without skipping and arginine)] occupied the main plot, two white maize hybrids (i.e. single cross - Fine Seeds-101 and three way cross- T.W. 329) were allocated in sub-plot. The experimental unit consisted of six ridges 4.5 meter in length and $80 \mathrm{~cm}$ between the ridges, the size of each plot was $21.6 \mathrm{~m}^{2}$. Grains of maize hybrids were sown on 20 and 28 May in both seasons, respectively, in hills spaced $25 \mathrm{~cm}$ along, three kernels per hill. After three weeks, plants were thinned to one plant / hill. Phosphorus fertilizer were added to soil before sowing at rate of $200 \mathrm{~kg} / \mathrm{fed}$., of calcium superphosphate $\left(15.5 \% \mathrm{P}_{2} \mathrm{O}_{5}\right)$. Nitrogen fertilizer as ammonium nitrate $(33.5 \% \mathrm{~N})$ was applied at the rate of $120 \mathrm{~kg} \mathrm{~N} /$ feddan.

The following growth characters were recorded on one samples of five guarded plants, was taken at ripe stage 90 days from sowing:

1- Plant height $(\mathrm{cm})$.

2- Total dry weight/plant (g).

3- Number of ear / plant.

4- Leaf area/ plant $\left(\mathrm{LA} \mathrm{dm}^{2}\right)$ was calculated according to Bremner and Taha (1966).

5- Leaf area index (LAI) was determined according to Watson (1952).

6- Leaf area ratio (LAR), (Blade leaf area in $\mathrm{dm}^{2} /$ whole plant dry weight in gram).

7- Specific leaf area (SLA), (Blade leaf area in $\mathrm{dm}^{2}$ /leaf dry weight in gram) was determined according to Abdel-Gawad et al. (1980).

8- Specific leaf weight (SLW g/ $\left.\mathrm{cm}^{2}\right)$, calculated according to Pearce et al. (1969).

Statistical analysis was performed according to procedure outlined by Gomez and Gomez (1984). Treatment means were compared by L.S.D. test at $5 \%$ level. Combined analysis was made for the two growing seasons as results followed similar trend.

\section{Results and Discussion}

\section{Growth parameters:}

\section{1-Omitting one irrigation and Arginine.}

Data in Table (2) showed that regardless of maize hybrids, the general mean of plant height $(\mathrm{cm})$, total dry weight / plant $(\mathrm{g})$, number of ear /plant, leaf area/ plant $\left(\mathrm{dm}^{2}\right)$, leaf area index, leaf 
area ratio, specific leaf area and specific leaf weight decreased when plant exposed to omitting $3^{\text {red }}$ or $4^{\text {th }}$ or $5^{\text {th }}$ irrigations, compared to the control (normal irrigation), the best treatment for all growth characters under study was control followed by omitting the $5^{\text {th }}$ irrigation, while foliar application with $200 \mathrm{~cm}^{3}$ arginine increased growth characters compared with without arginine, but no significantly differences between omitting $5^{\text {th }}$ irrigation + arginine and the control treatment in plant height. The reduction in plant height may be mainly due to the direct effect of limited water supply, which reflected in the reduction in metabolic products. May investigators reported that the height of maize plants was reduced when plants were subjected drought stress through decreasing number of irrigation intervals (Ahmed and Mekki, 2005). The dry matter accumulation in the different plant parts were significantly affected by irrigation treatments. In general, the plants received normal irrigation had more dry matter accumulation in plants. Similar finding were reported by El-Hattab et al (2000), Ahmed and Salem (2005), Ahmed et al (2009), Ahmed et al (2010) and Zaki et al (2014).

\section{2- Hybrid differences.}

Data in Table (2) showed that there were differences between the two white maize hybrids in all growth characters under study. Data reveled that Fine seeds-101 cultivar surpassed T.W 329 cultivar in plant height $(\mathrm{cm})$, total dry weight / plant $(\mathrm{g})$, number of ear /plant, leaf area/ plant $\left(\mathrm{dm}^{2}\right)$, leaf area index, leaf area ratio, specific leaf area and specific leaf weight in both seasons. The hybrid differences in growth parameter under this study may be due to the differences in genetic structure, and the hybrid differences in glucose required for synthesis of different chemical constituents at different plant organs, in carbon equivalent and in partitioning of photosynthates among the plants (Ahmed and Hassanein, 2000), also, to the great differences between genotypes for mineral element concentrations (Abou El-Seoud and Wafaa, 2010).

It is noteworthy that the hybrid differences in growth attributes herein in the study are in harmony with those obtained by Zaki et al (1999), Ahmed and Hassanein (2000), Kleinhenz (2003), El- Koomy et al (2005), Sadek et al (2006a,b), Mirdad (2010) and Ahmed et al (2011).

Table 2: Effect of Water regime and Cultivars on growth characters of maize hybrids. (Average of 2017 and 2018 seasons).

\begin{tabular}{|c|c|c|c|c|c|c|c|c|}
\hline Characters & $\begin{array}{c}\text { Plant } \\
\text { height } \\
\text { (cm) }\end{array}$ & $\begin{array}{c}\text { Total } \\
\text { d.w } \\
\text { /plant } \\
\text { (g ) }\end{array}$ & $\begin{array}{c}\text { No. } \\
\text { of } \\
\text { ear/plant }\end{array}$ & $\underset{\left(\mathbf{d m}^{2}\right)}{\mathbf{L A}}$ & LAI & LAR & SLA & SLW \\
\hline \multicolumn{9}{|l|}{ Water regime } \\
\hline Normal irrigation & 247.8 & 348.5 & 1.205 & 39.8 & 1.99 & 14.89 & 17.41 & 8.05 \\
\hline Omitting $3^{\text {rd }}$ irrigation & 228.1 & 331.1 & 1.012 & 33.4 & 1.67 & 13.34 & 13.71 & 6.39 \\
\hline Omitting $4^{\text {th }}$ irrigation & 236.6 & 339.6 & 1.070 & 35.2 & 1.76 & 13.51 & 14.35 & 6.66 \\
\hline Omitting $5^{\text {th }}$ irrigation & 244.0 & 345.4 & 1.120 & 36.8 & 1.84 & 13.77 & 15.04 & 6.89 \\
\hline Omitting $3^{\text {rd }}$ irrigation $+200 \mathrm{~cm}^{3}$ arginine & 235.7 & 336.7 & 1.085 & 35.0 & 1.75 & 14.00 & 14.70 & 7.04 \\
\hline Omitting $4^{\text {th }}$ irrigation $+200 \mathrm{~cm}^{3}$ arginine & 244.1 & 344.4 & 1.138 & 36.6 & 1.83 & 14.30 & 15.37 & 7.27 \\
\hline Omitting $5^{\text {th }}$ irrigation $+200 \mathrm{~cm}^{3}$ arginine & 247.5 & 346.3 & 1.175 & 38.5 & 1.93 & 14.65 & 16.50 & 7.67 \\
\hline L.S.D. at $5 \%$ & 1.5 & 1.1 & 0.009 & 0.8 & 0.04 & 0.01 & 0.02 & 0.01 \\
\hline \multicolumn{9}{|l|}{ Cultivars } \\
\hline Fine Seeds-101 & 246.7 & 346.9 & 1.126 & 37.9 & 1.89 & 14.67 & 16.32 & 7.35 \\
\hline T.W. 329 & 234.5 & 336.5 & 1.104 & 35.1 & 1.76 & 13.46 & 14.28 & 6.93 \\
\hline L.S.D. at $5 \%$ & 0.6 & 0.8 & 0.004 & 0.6 & 0.03 & 0.01 & 0.02 & 0.01 \\
\hline
\end{tabular}

D.W.: Dry weight, LA: Leaf area/ plant, LAI: Leaf area index, LAR: Leaf area ratio, SLA: Specific leaf area,

SLW: Specific leaf weight

\section{3- Effect of interaction.}

It is clear from Table (3) that the interaction between skipping one irrigation with or without arginine and maize hybrid was significant at all growth characters except leaf area/ plant $\left(\mathrm{dm}^{2}\right)$ and leaf area index. The best treatment for all growth characters was normal irrigation with Fine seeds101 cultivar followed by skipping $5^{\text {th }}$ irrigation $+200 \mathrm{~cm}^{3}$ arginine with Fine seeds- 101 cultivar for plant height $(\mathrm{cm})$, total dry weight / plant $(\mathrm{g})$ and leaf area ratio in both seasons. 
Table 3: Effect of interaction between Water regime $\mathrm{x}$ Cultivars on growth characters of maize hybrids. (Average of 2017 and 2018 seasons).

\begin{tabular}{|c|c|c|c|c|c|c|c|c|c|}
\hline Treatments & Characters & $\begin{array}{c}\text { Plant } \\
\text { height } \\
(\mathrm{cm})\end{array}$ & $\begin{array}{l}\text { Total d.w } \\
\text { /plant } \\
\text { ( g ) }\end{array}$ & $\begin{array}{c}\text { No. } \\
\text { of } \\
\text { ear/plant }\end{array}$ & $\underset{\left(\mathbf{d m}^{2}\right)}{\mathbf{L A}}$ & LAI & LAR & SLA & SLW \\
\hline \multicolumn{10}{|l|}{ Water regime $\mathrm{x}$ Cultivars } \\
\hline \multirow{2}{*}{ Normal irrigation } & Fine Seeds-101 & 254.6 & 352.6 & 1.230 & 41.5 & 2.07 & 15.22 & 18.37 & 8.44 \\
\hline & T.W. 329 & 241.0 & 344.3 & 1.180 & 38.2 & 1.91 & 14.55 & 16.45 & 7.67 \\
\hline \multirow{2}{*}{ Omitting $3^{\text {rd }}$ irrigation } & Fine Seeds-101 & 233.3 & 335.3 & 1.020 & 34.2 & 1.71 & 14.03 & 14.16 & 6.35 \\
\hline & T.W. 329 & 223.0 & 326.9 & 1.003 & 32.7 & 1.63 & 12.65 & 13.26 & 6.42 \\
\hline \multirow{2}{*}{ Omitting $4^{\text {th }}$ irrigation } & Fine Seeds-101 & 241.9 & 346.2 & 1.080 & 36.2 & 1.81 & 14.14 & 15.25 & 6.64 \\
\hline & T.W. 329 & 231.3 & 332.9 & 1.060 & 34.1 & 1.71 & 12.87 & 13.46 & 6.68 \\
\hline \multirow{2}{*}{ Omitting $5^{\text {th }}$ irrigation } & Fine Seeds-101 & 250.7 & 351.7 & 1.120 & 38.2 & 1.91 & 14.56 & 16.38 & 6.87 \\
\hline & T.W. 329 & 237.3 & 339.0 & 1.120 & 35.4 & 1.77 & 12.98 & 13.71 & 6.92 \\
\hline \multirow{2}{*}{$\begin{array}{l}\text { Omitting } 3^{\text {rd }} \text { irrigation }+200 \mathrm{~cm}^{3} \\
\text { arginine }\end{array}$} & Fine Seeds-101 & 242.4 & 342.1 & 1.083 & 36.3 & 1.82 & 14.74 & 15.49 & 7.35 \\
\hline & T.W. 329 & 229.1 & 331.4 & 1.087 & 33.7 & 1.69 & 13.26 & 13.92 & 6.72 \\
\hline \multirow{2}{*}{$\begin{array}{l}\text { Omitting } 4^{\text {th }} \text { irrigation }+200 \mathrm{~cm}^{3} \\
\text { arginine }\end{array}$} & Fine Seeds-101 & 249.3 & 348.9 & 1.150 & 37.8 & 1.89 & 14.93 & 16.47 & 7.58 \\
\hline & T.W. 329 & 239.0 & 339.9 & 1.127 & 35.4 & 1.77 & 13.67 & 14.26 & 6.96 \\
\hline \multirow{2}{*}{$\begin{array}{l}\text { Omitting } 5^{\text {th }} \text { irrigation }+200 \mathrm{~cm}^{3} \\
\text { arginine }\end{array}$} & Fine Seeds-101 & 254.3 & 351.7 & 1.197 & 40.9 & 2.05 & 15.08 & 18.12 & 8.21 \\
\hline & T.W. 329 & 240.7 & 341.0 & 1.153 & 36.1 & 1.81 & 14.21 & 14.89 & 7.13 \\
\hline L.S.D. at 5\% & & 1.6 & 2.2 & 0.012 & n.s & n.s & 0.03 & 0.06 & 0.03 \\
\hline
\end{tabular}

D.W.: Dry weight, LA: Leaf area/ plant, LAI: Leaf area index, LAR: Leaf area ratio, SLA: Specific leaf area,

SLW: Specific leaf weight

\section{References}

Abdel-Gawad, A.A., K.A.EL-Shouny, S.S. Saleh and M.A. Ahmed, 1980. The relation between the efficiency of leaf surface and the growth of some wheat cultivars in Egypt. Res. Bull 1412, Dec., pp 20, Fac. of Agric. Ain Shams Univ.

Abou EL-Seoud, I.I. A. and H.M. Wafaa, 2010. Phosphorus efficiency of different maize (Zea mays, L) genotypes grown on calcareous soil. Alex. Sci. Exch. J., 31(1): 1-9.

Ahmed, A.G., M.A. Bekheta and S.A. Orabi, 2010. Influence of arginine on growth and productivity of two sorghum cultivars grown under water shortage. International J. of Academic Research, 2(1):72-79.

Ahmed, M.A. and M.S. EL-S. Hassanein, 2000. Partition of photosynthates in yellow miaze hybrids. Egypt. J. Agron., 22: 39-63.

Ahmed, M.A., Magda, A.F. Shalaby and M.H. Afifi, 2009. Alleviation of water stress effects on maize by Mepiquat chloride. Modern J. of Appl. Biol. Sci. Crop Sci., 3 (2): 1-8.

Ahmed, M.A., Magda, A.F. Shalaby, M.A. Al-Kordy and M.S. Hassanein, 2011. Genetic analysis of energy production in white maize hybrids cultivated in newly cultivated sandy land. J. of Appl. Sci. Res., 7 (3): 346-356.

Ahmed, A.G. and B.B. Mekki, 2005. Yield and yield components of two maize hybrids as influenced by water deficit during different growth stages. Egyptian J. Appl. Sci., 20: 64-69.

Ahmed, A. G. and A.K.M. Salem, 2005. Response of grain sorghum (Sorghum bicolor L. Moench) to potassium fertilizer rates and omitting irrigation. Egypt. J. Agron., 27 (2):59 - 70.

Al-Hayani, E. H. H., 2018. Effect of foliar application of arginine on some growth parameters and the yield of vicia faba L. Biochem. Cell. Arch., 18 (1): 511-514.

Bremner, P.M. and M.A. Taha, 1966. Studies in potato agronomy, development and yield. J. Agric. Sci., 66: 241-252.

Chapman, H.D. and P.E. Pratt, 1961. Methods of Analysis for soils, Plants and Water. Univ. California. Berkeley, CA, USA.

EI-Bassiouny H. M. S., H. A. Mostafa, S. A. EI-Khawas, R. A. Hassanein, S.I. Khalil and A.A. Abd EI-Monem, 2008. Physiological responses of wheat plant to foliar treatments with arginine or putrescine. Austr J. of Basic and Applied Sci. 2(4), 1390-1403.

El- Hattab, A.H., S. A. Shaaban, D. M. El-Harriri, M.M. El-Gazzar and A.G. Ahmed, 2000. Growth characteristics, grain yield and quality of two sorghum cultivars as affected by skipping irrigation. Egypt. J. Appl. Sci., 15 (11): 168 -191. 
El koomy M.B.A., A.A. Abdel Gawad, A.M.A. Abo-Shetaia and G.M.A. Mahgoub, 2005. physiological exploration of certain maize inbred lines and hybrids by using rapid methods technique. 1. Genotypic differences. Arab Univ. J. Agric. Sci., Ain Shams Univ. Cairo, Egypt, 13: 297-307.

El- Sheikh, M.A., 1994. Response of two maize varieties to plant densities and irrigation treatments. J. Agric. Sci. Mansoura Univ., 19(2):413-422.

Gomez, A.K. and Gomez, A.A., 1984. Statistical procedure for agricultural Research. $2^{\text {nd }}$ edition John Wiley and Sons, Inc., New York.

Hefni, E.H. M., A. A. El-Hosary, M.I.M. Salwau and A. El- Shabbagh, 1993. Effect of soil moisture stress and zinc on some maize varieties. Ann. of Agric. Sci. Moshtohor, 31 (4):1813- 1828.

Ibrahim, M. E., H. M. M. El-Naggar and A. A. El-Hosary, 1992. Effect of irrigation intervals and plant densities on some varieties of corn. Menofiya J. Agric. Res. 17 (3):1083- 1098.

Kleinhenz, M.D., 2003. Sweet corn variety trails in ohio: Recent top performers and suggestions for future evaluations. Hort Technology, 13(4): 711-718.

Mirdad, Z.M., 2010. The effect of organic and inorganic fertilizers application on vegetative growth, yield and its components and chemical composition of two potato (Solanum tuberosum, L) cultivars. Alex. Sci. Exch. J., 31(1): 102-119.

Pearce, R. B., G.E. Carlson, D.K. Barny, R.H. Host and C.H. Hanson, 1969. Specific leaf weight and photosynthesis in alfalfa. Crop Sci., 9: 423-426.

Tarraf, S. A. and Nabila M. Zaki, 1999. Effect of yeast content on yield and chemical composition of clover plant. Egypt. J. Appl. Sci., 14 (10):136-155.

Sadek, S.E., M.A. Ahmed and T.A.E. Abdallah, 2006 a. Growth and yield analysis of nine different yellow mays genotypes grown in Egypt. J. of Applied Sci. Res., 2(3): 136-141.

Saked, S.E., M.A. Ahmed and A.M.M. Abd El- Aaal, 2006 b. Growth and yield analysis of fifteen white maize (Zea mays L.) genotypes developed in Egypt. J. of Applied Sci. Res., 2(6) 355-359.

Simpson, G. M., 1981. Water stress on plants .CBS Educational and Professional publishing, New York, U SA.

Watson, D.J., 1952.The physiological basis of variation in yield. Adv. Agron. 4:101- 145.

Winter, G., D. Christopher, M.T. Todd, F. Giuseppe and F. Dietmar, 2015. Physiological implication of arginine metabolism in plants. Frontiers in Plant Science Journal 6, Article 534.

Yang H. Q. and H. J. Gao, 2007. Physiological function of arginine and its metabolites in plants. Zhi Wu Sheng Li Yu Fen Zi Sheng Wu Xue Xue Bao. Journal of plant physiology and Molecular Biology 33(1), 1-8.

Zaki, N. M., Amal G. Ahmed, M. S. Hassanein, Manal F.M. and M. M. Tawfik, 2014. Yield and Yield Components of two Maize Hybrids as Influenced by Water Deficit and Amino cat Fertilizer. Middle East J. of Appl. Sci., 4(3): 648-654.

Zaki, N.M., M.M. EL-Gazzar, Karima M. Gamal EL-Din and M.A. Ahmed, 1999. Partition and migration of photosynthates in some maize hybrids. Egypt- J. Appl. Sci., 14(16): 117-139. 